\title{
UJI BAKTERI COLIFORM AIR MINUM ISI ULANG DI WILAYAH KERJA PUSKESMAS KALITANJUNG, KEJAKSAN, SUNYARAGI DENGAN METODE MPN TAHUN 2016
}

\section{TESTING OF COLIFORM BACTERIA IN DRINKING WATER REFILL IN THE WORKING AREA OF PUSKESMAS KALITANJUNG, KEJAKSAN, SUNYARAGI WITH METODE MOST PROBABLE NUMBER IN YEAR 2016}

\author{
Didi Rohadi ${ }^{1}$, Deni Firmansyah ${ }^{1}$, Iin Indawati ${ }^{1}$, Siti Pandanwangi ${ }^{1}$. \\ ${ }^{1}$ Akademi Farmasi Muhammadiyah Cirebon \\ Jl. Cideng Indah N0. 03 Cirebon \\ Email : didiaskun@yahoo.co.id
}

\begin{abstract}
ABSTRAK
Kebutuhan konsumsi air minum masyarakat yang tinggi memunculkan berbagai macam produk air minum, salah satu alternatifnya yaitu muncul air minum dalam kemasan (AMDK). Tetapi harga AMDK itu relatif mahal sehingga banyak bermunculan depot air minum isi ulang. Air minum yang sehat dan aman untuk dikonsumsi harus jernih, tidak berwarna, tidak berasa dan tidak berbau. Selain itu, air minum tersebut harus memenuhi persyaratan mikrobiologi yaitu tidak boleh mengandung bakteri patogen, misalnya golongan bakteri coliform. Tujuan penelitian ini adalah untuk mengetahui kandungan air minum isi ulang yang diteliti terdapat bakteri coliform. Penelitian dilakukan pada sampel yang diperoleh dari depot air minum isi ulang di wilayah kerja puskesmas Kalitanjung, Kejaksan, Sunyaragi, sebanyak 5 sampel tiap wilayah kerja puskesmas dengan metode MPN (Most Probable Number) yang terdiri dari tes perkiraan dengan menggunakan media lactose Broth (LB) dan tes penegasan dengan menggunakan media Brilliant Green Lactose Bile Broth (BGLB). Hasil penelitian menunjukkan bahwa dari 15 sampel air minum isi ulang yang diteliti terdapat 3 sampel yang positif coliform yaitu 1 sampel di wilayah kerja puskesmas Sunyaragi dengan nilai MPN 2,2, serta 2 sampel di wilayah kerja puskesmas Kalitanjung dengan nilai MPN 38 dan 240. Sehingga dari ketiga sampel yang positif tersebut tidak memenuhi syarat total coliform, karena dalam PERMENKES RI NO 492/Menkes/Per/IV/2010 menyatakan bahwa kadar maksimum yang diperbolehkan untuk parameter coliform pada air minum adalah 0 dalam 100ml sampel.
\end{abstract}

Kata Kunci: air minum isi ulang, coliform, metode MPN

\begin{abstract}
In This era consumtion of fresh water in Citizen is very high it is make many product of water for drink, and some alternative is bottled water ready to drink. But the price of Bottled Water was relatively expensive and that make appears many depot refill drinking water. Healthy drinking water and safe for consumption should be clear, colorless, tasteless and odorless. After that, water for drinks must Fullfil the requirements of microbiology that must not contain pathogenic bacteria, such as coliform bacteria group. The purpose of this study was to determine the content of refill drinking water studied contained coliform bacteria. The study was conducted on samples obtained from depot refill drinking water in the region of puskesmas Kalitanjung, Kejaksan, Sunyaragi, as many as five samples each working area of puskesmas with the method of MPN (Most Probable Number)
\end{abstract}


consisting of Persumptive Test by using the media lactose Broth (LB) and confirmative test using media Brilliant Green Lactose Bile Broth (BGLB). The results showed that of the 15 samples of drinking water refill studied three positive samples contained coliform, one sample in the working area of Puskesmas Sunyaragi with MPN value of 2.2, and 2 samples in the working area of Puskesmas Kalitanjung with MPN values of 38 and 240. Thus, of the three positive samples were not eligibility total coliform, because in PERMENKES RI No. 492 / Menkes / Per / IV / 2010 states that the maximum allowable levels for coliform parameters in drinking water is $0 \mathrm{in} 100 \mathrm{ml}$ sample.

Key Word: Drinking Water, Coliform, Most Probable Number Method

\section{PENDAHULUAN}

Air minum adalah air yang melalui proses pengolahan atau tanpa proses pengolahan yang memenuhi syarat kesehatan dan dapat langsung diminum (Anonim, 2010). Ketersediaan air bersih semakin berkurang seiring dengan perkembangan pertumbuhan penduduk. Di kota besar dalam hal pemenuhan kebutuhan air minum masyarakat mengkonsumsi air minum dalam kemasan (AMDK) karena praktis dan dianggap higienis (Polii, dkk, 2013). Namun harga AMDK dari berbagai merk yang relatif mahal menyebabkan AMDK sebagian besar hanya dikonsumsi oleh masyarakat tingkat ekonomi menengah keatas, sehingga masyarakat beralih mengkonsumsi air minum dari depot air minum isi ulang dengan harga yang lebih murah (Bambang, dkk, 2014).

Air minum yang sehat dan aman untuk dikonsumsi harus memenuhi persyaratan yang meliputi syarat fisik, kimia, dan bakteriologis. Syarat bakteriologis kualitas air minum dapat dilihat dari ada tidaknya bakteri coliform dalam air (Athena, dkk, 2004). Standar air minum di Indonesia mengikuti standar WHO dalam beberapa hal disesuaikan dengan kondisi di Indonesia. Pada tahun 2002, Departemen Kesehatan RI telah menetapkan kriteria kualitas air secara mikrobiologis, melalui Keputusan Menteri Kesehatan No.907 tahun 2002 bahwa air minum tidak diperbolehkan mengandung bakteri coliform dan Escherichia coli.

Berdasarkan studi tentang kualitas DAMIU yang dilakukan di laboratorium IPB yang menguji kualitas 120 sampel air minum isi ulang dari10 kota besar yaitu Jakarta, Tanggerang, Bekasi, Bogor, Cikampek, Medan, Denpasar, Yogyakarta, Semarang, dan Surabaya menunjukkan bahwa sekitar 16\% dari sampel tersebut terkontaminasi bakteri coliform yang mengindikasikan kualitas depot air minum isi ulang yang masih buruk (Pratiwi dalam Aulia, 2013).

Dalam penelitian ini akan dipelajari apakah air minum yang diperoleh dari depot air minum isi ulang di wilayah kerja puskesmas Kalitanjung, Kejaksan, dan Sunyaragi mengandung bakteri coliform.

\section{METODE PENELITIAN}

\section{Alat dan Bahan}

Alat: Autoklaf (All American), Incubator (Memmert), Laminary air flow (AirTech), neraca , rak tabung reaksi, tabung reaksi (Pyrex), lemari es, botol sampel steril, lampu spiritus, pinset, tabung durham (Pyrex), pipet ukur $10 \mathrm{ml}$ (Iwaki), pipet ukur 0,1 ml (Iwaki), pipet ukur $1 \mathrm{ml}$ (Iwaki), label, Bunsen, Kertas perkamen, Labu ukur $100 \mathrm{ml}$ (Pyrex), Erlenmeyer $1000 \mathrm{ml}$ (Pyrex), batang pengaduk, Jarum ose bulat, Kapas dan kasa steril.

Bahan: Air dari Depo air minum (sampel), Aquadest steril, Laktose Broth (Oxoid), Brilliant Green Laktose Bile Broth (BGLB) $2 \%$ (Oxoid). 


\section{Jalannya Penelitian}

1. Pembuatan media

a. Lactose Broth

Timbang dan masukkan 13 gram lactose broth dalam $1000 \mathrm{ml}$ aquadest aduk sampai larut sempurna. Tuang dengan pipet volume $10 \mathrm{ml}$ ke dalam tabung reaksi yang berisi tabung durham, sterilkan dengan autoklaf suhu $121^{\circ} \mathrm{C}$ selama 15 menit.

b. Brilliant Green Lactose Bile Broth (BGLB)

Timbang dan masukkan 40 gram lactose broth dalam $1000 \mathrm{ml}$ aquadest aduk sampai larut sempurna. Tuang dengan pipet volume $10 \mathrm{ml}$ ke dalam tabung reaksi yang berisi tabung durham, steriilkan dengan autoklaf suhu $121^{\circ} \mathrm{C}$ selama 15 menit.

2. Pengambilan sampel

Ambil botol steril untuk pengambilan sampel. Ambil $\pm 200 \mathrm{ml}$ sampel dari Depo secara aseptik. Catat waktu pengambilan

3. Pengenceran sampel

Sampel yang didapat dikocok terlebih dahulu. Masukkan $10 \mathrm{ml}$ sampel kedalam labu ukur $100 \mathrm{ml}$. Tuangkan aquadest steril kedalam labu ukur sampai batas labu. Kocok sebanyak kurang lebih 25 kali sampai homogen. Sampel yang sudah diencerkan siap digunakan untuk pemeriksaan.

4. Tes perkiraan (Persumptive Test)

Siapkan 7 tabung reaksi yang masing-masing berisi media laktosa broth sebanyak $10 \mathrm{ml}$ dan tabung durham. Tabung disusun pada rak tabung reaksi, masing-masing tabung diberi tanda : nomor urut, volume, tanggal pemeriksaan, dengan pipet steril ambil bahan pemeriksaan yang telah disiapkan, masukkan kedalam tabung 1 sampai 5 masing-masing sebanyak $10 \mathrm{ml}$. tabung ke 6 sebanyak $1 \mathrm{ml}$ dan tabung ke 7 sebanyak $0,1 \mathrm{ml}$. Inkubasikan pada suhu $35^{\circ} \mathrm{C}$ sampai dengan $37^{\circ} \mathrm{C}$ selama 24 jam. Setelah 24 jam periksa ada tidaknya pembentukan gas pada tabung durham. Catat semua tabung yang menunjukkan peragian laktosa (membentuk gas). Apabila terjadi pembentukan gas pada tabung durham, pada tes perkiraan dinyatakan + (positif) dan maka dilanjutkan dengan tes penegasan.

5. Tes Penegasan (Confirmative Test)

Dari tiap tabung tes perkiraan (presumptive test) yang positif, pindahkan $1-2$ ose kedalam masing-masing tabung tes penegasan (Confirmative Test) yang berisi $10 \mathrm{ml}$ BGLB $2 \%$ dan tabung durham. Satu seri tabung BGLB $2 \%$ di inkubasikan pada suhu $35^{\circ} \mathrm{C}$ sampai dengan $37^{\circ} \mathrm{C}$ selama 24 jam -48 jam ( untuk memastikan adanya Coliform). Pembacaan dilakukan setelah $24-48$ jam dengan melihat jumlah tabung BGLB 2\% yang menunjukkan positif gas. Dari hasil tes penegasan yang diperoleh, dicocokkan dengan tabel MPN.

\section{HASIL DAN PEMBAHASAN}

1. Tes Perkiraan

\section{Tabel 1. Hasil Tes Perkiraan pada Air Minum Isi Ulang di Wilayah Kerja Puskesmas Kalitanjung Kota Cirebon Tahun 2016 dengan media Lactose Broth (LB)}

\begin{tabular}{|c|c|c|c|c|c|c|c|}
\hline \multirow{2}{*}{ Nama sampel } & \multicolumn{7}{|c|}{ Volume sampel } \\
\cline { 2 - 8 } & $\begin{array}{c}10 \mathrm{ml} \\
(1)\end{array}$ & $\begin{array}{c}10 \mathrm{ml} \\
(2)\end{array}$ & $\begin{array}{c}10 \mathrm{ml} \\
(3)\end{array}$ & $\begin{array}{c}10 \mathrm{ml} \\
(4)\end{array}$ & $\begin{array}{c}10 \mathrm{ml} \\
(5)\end{array}$ & $\begin{array}{c}1 \mathrm{ml} \\
(6)\end{array}$ & $\begin{array}{c}0.1 \mathrm{ml} \\
(7)\end{array}$ \\
\hline AMIU-01 & $(-)$ & $(-)$ & $(-)$ & $(-)$ & $(-)$ & $(-)$ & $(-)$ \\
\hline AMIU-02 & $(-)$ & $(-)$ & $(-)$ & $(-)$ & $(-)$ & $(-)$ & $(-)$ \\
\hline AMIU-03 & $(-)$ & $(-)$ & $(-)$ & $(-)$ & $(-)$ & $(-)$ & $(-)$ \\
\hline AMIU-04 & $(+)$ & $(+)$ & $(+)$ & $(+)$ & $(+)$ & $(-)$ & $(-)$ \\
\hline AMIU-05 & $(+)$ & $(+)$ & $(+)$ & $(+)$ & $(+)$ & $(+)$ & $(+)$ \\
\hline
\end{tabular}

Ket: $(+)=$ Menghasilkan gas

$(-)$ = Tidak menghasilkan gas 
Didi Rohadi dkk

Tabel 2. Hasil Tes Perkiraan pada Air Minum Isi Ulang di Wilayah Kerja Puskesmas Kejaksan Kota Cirebon Tahun 2016 dengan media Lactose Broth (LB)

\begin{tabular}{|c|c|c|c|c|c|c|c|}
\hline \multirow{2}{*}{$\begin{array}{c}\text { Nama } \\
\text { sampel }\end{array}$} & \multicolumn{7}{|c|}{ Volume sampel } \\
\cline { 2 - 8 } & $\begin{array}{c}10 \mathrm{ml} \\
(1)\end{array}$ & $\begin{array}{c}10 \mathrm{ml} \\
(2)\end{array}$ & $\begin{array}{c}10 \mathrm{ml} \\
(3)\end{array}$ & $\begin{array}{c}10 \mathrm{ml} \\
(4)\end{array}$ & $\begin{array}{c}10 \mathrm{ml} \\
(5)\end{array}$ & $\begin{array}{c}1 \mathrm{ml} \\
(6)\end{array}$ & $\begin{array}{c}0.1 \mathrm{ml} \\
(7)\end{array}$ \\
\hline AMIU-01 & $(-)$ & $(-)$ & $(-)$ & $(-)$ & $(-)$ & $(-)$ & $(-)$ \\
\hline AMIU-02 & $(+)$ & $(+)$ & $(-)$ & $(-)$ & $(-)$ & $(-)$ & $(-)$ \\
\hline AMIU-03 & $(-)$ & $(-)$ & $(-)$ & $(-)$ & $(-)$ & $(-)$ & $(-)$ \\
\hline AMIU-04 & $(-)$ & $(-)$ & $(-)$ & $(-)$ & $(-)$ & $(-)$ & $(-)$ \\
\hline AMIU-05 & $(-)$ & $(-)$ & $(-)$ & $(-)$ & $(-)$ & $(-)$ & $(-)$ \\
\hline
\end{tabular}

Ket: $(+)=$ Menghasilkan gas

$(-)$ = Tidak menghasilkan gas

Tabel 3. Hasil Tes Perkiraan pada Air Minum Isi Ulang di Wilayah Kerja Puskesmas Sunyaragi Kota Cirebon Tahun 2016 dengan media Lactose Broth (LB)

\begin{tabular}{|c|c|c|c|c|c|c|c|}
\hline & \multicolumn{7}{|c|}{ Volume sampel } \\
\cline { 2 - 8 } Nama sampel & $\begin{array}{c}10 \mathrm{ml} \\
(1)\end{array}$ & $\begin{array}{c}10 \mathrm{ml} \\
(2)\end{array}$ & $\begin{array}{c}10 \mathrm{ml} \\
(3)\end{array}$ & $\begin{array}{c}10 \mathrm{ml} \\
(4)\end{array}$ & $\begin{array}{c}10 \mathrm{ml} \\
(5)\end{array}$ & $\begin{array}{c}1 \mathrm{ml} \\
(6)\end{array}$ & $\begin{array}{c}0.1 \mathrm{ml} \\
(7)\end{array}$ \\
\hline AMIU-01 & $(-)$ & $(-)$ & $(-)$ & $(-)$ & $(-)$ & $(-)$ & $(-)$ \\
\hline AMIU-02 & $(-)$ & $(-)$ & $(-)$ & $(-)$ & $(-)$ & $(-)$ & $(-)$ \\
\hline AMIU-03 & $(-)$ & $(-)$ & $(-)$ & $(-)$ & $(-)$ & $(-)$ & $(-)$ \\
\hline AMIU-04 & $(+)$ & $(-)$ & $(-)$ & $(-)$ & $(-)$ & $(-)$ & $(-)$ \\
\hline AMIU-05 & $(+)$ & $(-)$ & $(-)$ & $(-)$ & $(-)$ & $(-)$ & $(-)$ \\
\hline
\end{tabular}

Ket: $(+)=$ Menghasilkan gas

$(-)$ = Tidak menghasilkan gas

2. Tes Penegasan

Tabel 4. Hasil Tes Penegasan pada Air Minum Isi Ulang di Wilayah Kerja Puskesmas Kalitanjung Kota Cirebon Tahun 2016 dengan media Brilliant Green Lactose Bile Broth (BGLB)

\begin{tabular}{|c|c|c|c|c|c|c|c|}
\hline \multirow{2}{*}{ Nama sampel } & \multicolumn{7}{|c|}{ Volume sampel } \\
\cline { 2 - 9 } & $\begin{array}{c}10 \mathrm{ml} \\
(1)\end{array}$ & $\begin{array}{c}10 \mathrm{ml} \\
(2)\end{array}$ & $\begin{array}{c}10 \mathrm{ml} \\
(3)\end{array}$ & $\begin{array}{c}10 \mathrm{ml} \\
(4)\end{array}$ & $\begin{array}{c}10 \mathrm{ml} \\
(5)\end{array}$ & $\begin{array}{c}1 \mathrm{ml} \\
(6)\end{array}$ & $\begin{array}{c}0.1 \mathrm{ml} \\
(7)\end{array}$ \\
\hline AMIU-04 & $(+)$ & $(+)$ & $(+)$ & $(+)$ & $(+)$ & & \\
\hline AMIU-05 & $(+)$ & $(+)$ & $(+)$ & $(+)$ & $(+)$ & $(+)$ & $(+)$ \\
\hline
\end{tabular}

Ket: $(+) \quad=$ Menghasilkan gas

$(-) \quad=$ Tidak menghasilkan gas

$=$ Tidak dilakukan pengujian 
Didi Rohadi dkk

Tabel 5. Hasil Tes Penegasan pada Air Minum Isi Ulang di Wilayah Kerja Puskesmas Kejaksan Kota Cirebon Tahun 2016 dengan media Brilliant Green Lactose Bile Broth (BGLB)

\begin{tabular}{|c|c|c|c|c|c|c|c|}
\hline \multirow{2}{*}{ Nama sampel } & \multicolumn{7}{|c|}{ Volume sampel } \\
\cline { 2 - 8 } & $\begin{array}{c}10 \mathrm{ml} \\
(1)\end{array}$ & $\begin{array}{c}10 \mathrm{ml} \\
(2)\end{array}$ & $\begin{array}{c}10 \mathrm{ml} \\
(3)\end{array}$ & $\begin{array}{c}10 \mathrm{ml} \\
(4)\end{array}$ & $\begin{array}{c}10 \mathrm{ml} \\
(5)\end{array}$ & $\begin{array}{c}1 \mathrm{ml} \\
(6)\end{array}$ & $\begin{array}{c}0.1 \mathrm{ml} \\
(7)\end{array}$ \\
\hline AMIU-04 & $(-)$ & $(-)$ & & & & & \\
\hline
\end{tabular}

Ket: $(+) \quad=$ Menghasilkan gas

$(-) \quad=$ Tidak menghasilkan gas

$=$ Tidak dilakukan pengujian

Tabel 6. Hasil Tes Penegasan pada Air Minum Isi Ulang di Wilayah Kerja Puskesmas Sunyaragi Kota Cirebon Tahun 2016 dengan media Brilliant Green Lactose Bile Broth (BGLB)

\begin{tabular}{|c|c|c|c|c|c|c|c|}
\hline & \multicolumn{7}{|c|}{ Volume sampel } \\
\cline { 2 - 7 } Nama sampel & $\begin{array}{c}10 \mathrm{ml} \\
(1)\end{array}$ & $\begin{array}{c}10 \mathrm{ml} \\
(2)\end{array}$ & $\begin{array}{c}10 \mathrm{ml} \\
(3)\end{array}$ & $\begin{array}{c}10 \mathrm{ml} \\
(4)\end{array}$ & $\begin{array}{c}10 \mathrm{ml} \\
(5)\end{array}$ & $\begin{array}{c}1 \mathrm{ml} \\
(6)\end{array}$ & $\begin{array}{c}0.1 \mathrm{ml} \\
(7)\end{array}$ \\
\hline AMIU-04 & $(-)$ & & & & & &
\end{tabular}

Ket: $(+) \quad=$ Menghasilkan gas

$(-) \quad=$ Tidak menghasilkan gas

=Tidak dilakukan pengujian

3. Hasil Pemeriksaan Mikrobiologi

Tabel 7. Hasil Pemeriksaan Mikrobiologi pada Air Minum Isi Ulang di $\quad$ Wilayah $\quad$ Kerja Puskesmas Kalitanjung Kota Cirebon Tahun 2016.

\begin{tabular}{|c|c|c|c|c|c|}
\hline $\begin{array}{c}\text { Nama } \\
\text { sampel }\end{array}$ & Pemeriksaan & $\begin{array}{c}\text { Batas } \\
\text { maksimal }\end{array}$ & Satuan & $\begin{array}{c}\text { Hasil } \\
\text { pemeriksaan }\end{array}$ & Keterangan \\
\hline AMIU-01 & $\begin{array}{c}\text { MPN } \\
\text { Coliform }\end{array}$ & 0 & $\begin{array}{c}\text { Per 100ml } \\
\text { sampel }\end{array}$ & 0 & Memenuhi syarat \\
\hline AMIU-02 & $\begin{array}{c}\text { MPN } \\
\text { Coliform }\end{array}$ & 0 & $\begin{array}{c}\text { Per 100ml } \\
\text { sampel }\end{array}$ & 0 & Memenuhi syarat \\
\hline AMIU-03 & $\begin{array}{c}\text { MPN } \\
\text { Coliform }\end{array}$ & 0 & $\begin{array}{c}\text { Per } 100 \mathrm{ml} \\
\text { sampel }\end{array}$ & 0 & Memenuhi syarat \\
\hline AMIU-04 & $\begin{array}{c}\text { MPN } \\
\text { Coliform }\end{array}$ & 0 & $\begin{array}{c}\text { Per } 100 \mathrm{ml} \\
\text { sampel }\end{array}$ & 38 & $\begin{array}{c}\text { Tidak Memenuhi } \\
\text { syarat }\end{array}$ \\
\hline AMIU-05 & $\begin{array}{c}\text { MPN } \\
\text { Coliform }\end{array}$ & 0 & $\begin{array}{c}\text { Per } 100 \mathrm{ml} \\
\text { sampel }\end{array}$ & 240 & $\begin{array}{c}\text { Tidak } \\
\text { Memenuhi syarat }\end{array}$ \\
\hline
\end{tabular}


Tabel 8. Hasil Pemeriksaan Mikrobiologi pada Air Minum Isi Ulang di

Wilayah

Kerja Puskesmas Kejaksan Kota Cirebon Tahun 2016.

\begin{tabular}{|c|c|c|c|c|c|}
\hline $\begin{array}{c}\text { Nama } \\
\text { sampel }\end{array}$ & Pemeriksaan & $\begin{array}{c}\text { Batas } \\
\text { maksimal }\end{array}$ & Satuan & $\begin{array}{c}\text { Hasil } \\
\text { pemeriksaan }\end{array}$ & Keterangan \\
\hline AMIU-01 & $\begin{array}{c}\text { MPN } \\
\text { Coliform }\end{array}$ & 0 & $\begin{array}{c}\text { Per 100ml } \\
\text { sampel }\end{array}$ & 0 & Memenuhi syarat \\
\hline AMIU-02 & $\begin{array}{c}\text { MPN } \\
\text { Coliform }\end{array}$ & 0 & $\begin{array}{c}\text { Per 100ml } \\
\text { sampel }\end{array}$ & 0 & Memenuhi syarat \\
\hline AMIU-03 & $\begin{array}{c}\text { MPN } \\
\text { Coliform }\end{array}$ & 0 & $\begin{array}{c}\text { Per 100ml } \\
\text { sampel }\end{array}$ & 0 & Memenuhi syarat \\
\hline AMIU-04 & $\begin{array}{c}\text { MPN } \\
\text { Coliform }\end{array}$ & 0 & $\begin{array}{c}\text { Per 100ml } \\
\text { sampel }\end{array}$ & 0 & Memenuhi syarat \\
\hline AMIU-05 & $\begin{array}{c}\text { MPN } \\
\text { Coliform }\end{array}$ & 0 & $\begin{array}{c}\text { Per 100ml } \\
\text { sampel }\end{array}$ & 0 & Memenuhi syarat \\
\hline
\end{tabular}

Tabel 9. Hasil Pemeriksaan Mikrobiologi pada Air Minum Isi Ulang di Puskesmas Kejaksan Kota Cirebon Tahun 2016.

Wilayah Kerja

\begin{tabular}{|c|c|c|c|c|c|}
\hline $\begin{array}{c}\text { Nama } \\
\text { sampel }\end{array}$ & Pemeriksaan & $\begin{array}{c}\text { Batas } \\
\text { maksimal }\end{array}$ & Satuan & $\begin{array}{c}\text { Hasil } \\
\text { pemeriksaan }\end{array}$ & Keterangan \\
\hline AMIU-01 & $\begin{array}{c}\text { MPN } \\
\text { Coliform }\end{array}$ & 0 & $\begin{array}{c}\text { Per } 100 \mathrm{ml} \\
\text { sampel }\end{array}$ & 0 & Memenuhi syarat \\
\hline AMIU-02 & $\begin{array}{c}\text { MPN } \\
\text { Coliform }\end{array}$ & 0 & $\begin{array}{c}\text { Per } 100 \mathrm{ml} \\
\text { sampel }\end{array}$ & 0 & Memenuhi syarat \\
\hline AMIU-03 & $\begin{array}{c}\text { MPN } \\
\text { Coliform }\end{array}$ & 0 & $\begin{array}{c}\text { Per } 100 \mathrm{ml} \\
\text { sampel }\end{array}$ & 0 & Memenuhi syarat \\
\hline AMIU-04 & $\begin{array}{c}\text { MPN } \\
\text { Coliform }\end{array}$ & 0 & $\begin{array}{c}\text { Per } 100 \mathrm{ml} \\
\text { sampel }\end{array}$ & 0 & $\begin{array}{c}\text { Tidak Memenuhi } \\
\text { syarat }\end{array}$ \\
\hline AMIU-05 & $\begin{array}{c}\text { MPN } \\
\text { Coliform }\end{array}$ & 0 & $\begin{array}{c}\text { Per } 100 \mathrm{ml} \\
\text { sampel }\end{array}$ & 2,2 & $\begin{array}{c}\text { Tidak } \\
\text { Memenuhi syarat }\end{array}$ \\
\hline
\end{tabular}

Hasil uji dari 15 sampel air minum isi ulang yang ada di 3 wilayah kerja Puskesmas kota Cirebon yaitu puskesmas Kalitanjung, Kejaksan, Sunyaragi, maka didapatkan hasil yaitu 2 sampel (AMIU-04 dan AMIU-05) positif terkandung bakteri coliform pada sampel di wilayah kerja puskesmas Kalitanjung dan 1 sampel (AMIU-05) yang positif yang terdapat di wilayah kerja puskesmas Sunyaragi sedangkan di wilayah kerja puskesmas Kejaksan tidak ditemukan sampel yang mengandung bakteri coliform.

Menurut Lary W dalam Pratiwi (2007) Faktor-faktor dan kondisi yang menyebabkan kualitas bakteriologis air pada depot air minum isi ulang tidak memenuhi standar kesehatan, meliputi:

1. Bakteri total coliform dan E.coli ada di air minum dikarenakan adanya kontaminasi pada peralatan pengolahan air minum, pengetahuan akan higienis operator penjamah/pemilik depot masih kurang, sanitasi tempat pengolahan air minum atau sistem distribusi pada pipa penyalur air minum.

2. Saat pengambilan sampel air minum, depot air minum isi ulang dalam proses pengolahan air, sehinga belum terjadinya pengendapan. Hal ini bisa menyebabkan timbulnya kekeruhan pada air minum sehingga akan memicu pertumbuhan bakteri.

3. Temperatur penyimpanan sampel air minum yang dapat meningkatkan pertumbuhan bakteri. Bakteri coliform membutuhkan suhu $35^{\circ} \mathrm{C}$ sebagai suhu optimal untuk berkembang biak, 
Didi Rohadi dkk

sedangkan bakteri Escherichia coli membutuhkan $37^{\circ} \mathrm{C}$ sebagai suhu optimal untuk berkembang biak.

4. Tidak optimal pada saat melakukan sistem desinfeksi/sterilisasi Terutama depot yang menggunakan sistem desinfeksi/ sterilisasi dengan ultraviolet. Mekanisme kerja ultraviolet adalah memancarkan sinar radiasi yang dapat menyebabkan perubahan pada molekuler dalam komponen biochemical bakteri. Kekuatan sinar ultraviolet untuk membunuh mikroorganisme adalah $254 \mathrm{~nm}$ energi ultraviolet.

5. Selama operasional, efektifitas alat tidak diperhatikan oleh pemilik depot air minum isi ulang. Pada proses penyaringan dengan menggunakan filter catridge yang berdiameter 0,5 mikron dan penyinaran dengan ultraviolet seharusnya mampu menghilangkan kandungan bakteri dalam air minum isi ulang.

\section{KESIMPULAN}

1. Dari hasil penelitian bakteri coliform pada air minum isi ulang di wilayah kerja puskesmas Kalitanjung, diketahui bahwa air minum isi ulang yang diuji terdapat 2 dari 5 sampel mengandung bakteri coliform dengan MPN (Most Probable Number) 38 / $100 \mathrm{ml}$ dan 240 / 100 $\mathrm{ml}$.

2. Dari hasil penelitian bakteri coliform pada air minum isi ulang di wilayah kerja puskesmas Kejaksan, diketahui bahwa air minum isi ulang yang diuji tidak terdapat sampel yang mengandung bakteri coliform.

3. Dari hasil penelitian bakteri coliform pada air minum isi ulang di wilayah kerja puskesmas sunyaragi, diketahui bahwa air minum isi ulang yang diuji terdapat 1 dari 5 sampel mengandung bakteri coliform dengan MPN (Most Probable Number) 2,2 / $100 \mathrm{ml}$.

4. Tiga sampel air minum isi ulang yang positif mengandung bakteri coliform tersebut tidak memenuhi persyaratan yang ditetapkan oleh Peraturan Menteri Kesehatan Republik Indonesia Nomor: 492/MENKES/Per/IV/2010 dimana kadar maksimum yang diperbolehkan untuk parameter total bakteri coliform pada air minum adalah 0 per $100 \mathrm{ml} \mathrm{sampel.}$

\section{DAFTAR PUSTAKA}

Anonim, 2010, Peraturan Menteri Kesehatan Republik Indonesia Nomor 492/Menkes/Per/IV/2010 Tentang Persyaratan Kualitas Air Minum, Jakarta: Depkes RI.

Anonim, 2002, Keputusan Menteri Kesehatan Republik Indonesia Nomor 907/Menkes/SK/VII/2002 Tentang Syarat-Syarat dan Pengawasan Kualitas Air Minum, Jakarta: Depkes RI.

Anonim, 1991, Petunjuk Pemeriksaan Mikrobiologi Makanan dan Minuman, Departemen Kesehatan RI Pusat Laboratorium Kesehatan.

Athena S, M Hendro, Anwar MD \& Haryono. 2004. Kandungan Bakteri Total Coli Dan Escherichia Coli/Fecal Coli Pada Air Minum Isi Ulang Di Jakarta. Tangerang dan Bekasi. Penelitian Kesehatan

Aulia F.N, 2013, Skripsi Analisis Keberadaan Mikroba Pada Air Baku PDAM Kabupaten Situbondo, Fakultas Matematika dan Ilmu Pengetahuan Alam, Universitas Jember, Jember.

Bambang, Adriana G., Fatimawali, dan Novel, S.Kojong, 2014, Analisis Cemaran Bakteri Coliform dan Identifikasi Escherichia coli Pada Air Isi Ulang Dari Depot di Kota Manado, Skripsi. Jurusan Farmasi. Fakultas Matematika dan Ilmu Pengetahuan Alam. Universitas Sam Ratulangi. 
Didi Rohadi dkk

Polii B, Risky B.T, Sammy S, 2013, Jurnal Analisis Kualitatif Kandungan Escherichia Coli dan Coliform Pada 3 Depot Air Minum Isi Ulang di Kota Manado, Fakultas Kesehatan Masyarakat, Universitas Sam Ratulangi, Manado.

Pratiwi A.W, 2007, Jurnal Kesehatan Masyarakat Nasional Vol.2 Kualitas Bakteriologis Air Minum Isi Ulang. 